\title{
THE CONTEMPORARY CHALLENGES OF MEASURING POLITICAL PARTICIPATION ${ }^{1}$
}

\author{
Yerkebulan Sairambay ${ }^{2}$
}

\begin{abstract}
The multifaceted nature of political participation has led to various ways of measuring it. This, in turn, has led to conflicting outcomes (even when applied to the same problem) in the research field. What are the contemporary challenges of measuring political participation? The main objective of this paper is to identify current challenges of measuring political participation that are common in the existing literature and empirical findings. This review paper examines different methods of measuring both online and offline political participation and shows current problems that are crucial to deal with methodological challenges in the emerging era of Web 3.0. Drawing from a careful analysis of 86 published (2012-2019) empirical research on new media and political participation, the present study finds that self-reported measures, different question-wordings, misuse of Likert scales and time frames, and the lack of clear concept of political participation are current problems of measuring political participation. In so doing, it contributes to research on political participation (1) attempting to gather various measurements and their common problems as well as (2) urging the importance of these challenges.
\end{abstract}

KEY WORDS: Political participation, Measuring political participation, Research methods, Measurement challenges.

\section{INTRODUCTION}

The ways of measuring political participation are problematic and demand a study that addresses the main challenges they encounter through reviewing the literature, empirical findings, and the recent developments of new media and civil societies, which have provided citizens with the new modes of political actions. Although some papers (e.g. Saunders, 2014; Persson, Solevid, 2014; Eder, Stadelmann-Steffen, 2017; Dimitrova, Matthes, 2018; Strömbäck, et al. 2018) capture the separate problems of

\footnotetext{
${ }^{1}$ This study was funded by the 'Bolashak' programme (Grant № 15-1/25967).

I would like to thank Dr. David Lane (Emeritus Fellow, Emmanuel College, Cambridge University) and two anonymous reviewers for their insightful comments and challenging questions that helped to shape this article.

${ }^{2}$ Department of Sociology, University of Cambridge, 16 Mill Lane, Cambridge, CB2 1SB, United Kingdom, e-mail: YS500@cam.ac.uk, ORCID: 0000-0003-2836-4765.
} 
measuring political participation, many scholarly works do not deal with methodological challenges; rather they tend to repeat existing problems or lead to various conflicting outcomes (e.g. see Rucht, 2007; Stoker, et al. 2011). One possible explanation of this trend could be the lack of study that examines the current challenges of measuring political participation. The present article sheds light on this issue through reviewing and discussing the literature and empirical findings on measuring both online and offline political participation.

The current WWW can be characterised as a mixture of participative Web 2.0 and the rising collaborative Web 3.0 because there are elements of both Web developments. Consequently, the emerging era of Web 3.0 provides multiple platforms for online political participation, which is gaining a momentum worldwide and contributing to the multifaceted nature of political participation. Offline political participation has also expanded in recent decades. For example, new political actions such as participatory budgeting and 'buycotting' were not part of political systems several decades ago. Considering this multidimensionality, the question that arises in this context is about whether there are common problems of various research methods employed to study political participation.

The following online tools have been used to find scholarly works on the common problems of measuring political participation:

a) http://idiscover.lib.cam.ac.uk/ - Cambridge University's online search tool for its libraries and online resources, including ebooks and ejournals;

b) https://www.gla.ac.uk/myglasgow/library/ - Glasgow University's online search tool for its libraries and online resources, including ebooks and ejournals;

c) https://scholar.google.com/.

The results of search showed some glimpses of measuring political participation, but there is not a single study addressing its contemporary challenges in the emerging era of Web 3.0. The main objective of this paper ${ }^{3}$ is to identify the current challenges of measuring political participation that are common in the existing literature and empirical findings in order to urge their importance. The research objective of the present study is achieved through an extensive review of the relevant literature and through a careful analysis of 86 published (2012-2019) empirical research dedicated on

${ }^{3}$ The paper is a part of the on-going five-year project on new media and political participation hosted at the University of Cambridge. 
new media and political participation. These scholarly works were chosen using some key words such as 'political participation', 'new media', 'civic engagement', 'offline participation', and 'online activism' as well as reading the abstracts of empirical articles. The timeframe between 2012 and 2019 was chosen to focus on empirical research findings in the context of both participative Web 2.0 and the emerging collaborative Web 3.0 era. This work therefore limits its findings within the frames of new media and political participation studies. That is, the other strands of political participation research, such as psychology and political participation, civic engagement and political participation, and political interest and political participation, have not been analysed. The data was processed using content analysis to meet the research objective. In so doing, the patterns of common challenges were examined through systematic reading and observation of texts labelling (coding) their contents. The selected articles were coded for five dimensions: the lack of acknowledging measuring challenges, Likert scale challenges, self-reported measures \& different question-wordings, timeframe problems, and conceptual challenges. For the coding scheme, please see Table 1. During the content analysis, it was possible to find one article in more than one coding, which means some papers had several challenges.

This article is divided into three sections. The first section discusses the development of various measurements, providing the literature review. In order to better understand and differentiate political participation modes, measuring online and offline political participation is analysed in the second section. In the third section, the current problems of measuring political participation are examined to achieve the objective of this paper.

\section{HOW TO MEASURE POLITICAL PARTICIPATION?}

This section explores the various tools, determinants, and measurements of political participation ranging from the conventional forms of political participation, such as voting, to individual orientations and other forms of citizens' repertoires, taking into account different political and cultural contexts and their various characteristics. In addition, it provides various methods employed in measuring political participation.

Scholars are mostly "interested in the participatory characteristics of ordinary people with no political posts rather than people who specifically seek political power". (Sairambay, 2020, p. 124). Those who lead/manipulate/organise participants can also be considered in political 
participation research, unless they intentionally seek the political posts of political power. The multifaceted nature of political participation has led to various ways of measuring it. Traditionally, voter turnout is used as one way of measuring political participation (Rolfe, 2012), as voting "is the most important and visible form of political participation" (Whiteley, 2012, p. 37). Although of crucial importance, focusing only on voting does not create a complete picture of political participation in the contemporary research, as it omits other forms of a citizen's repertoires (Sheppard, 2015, p. 2). Even in the last century, some scholars have already used many items to measure political participation. For example, Inkeles (1969, p. 1124) conducted cross-national comparisons of individual orientations to politics through questionnaires. The questionnaires included 33 items such as "attitudes towards citizenship obligations, identification with the nation-state, and the degree and forms of the individual's participation in politics". Similarly, Deth (1986, p. 265) measured political participation in a comparative research of eight countries selecting 19 items and applying Prezeworski and Teune's 'identity-equivalence procedure', and found it 'to be very useful for an exploration of the cross-national differences of the troublesome concept 'political participation"'. This method starts with "the selection of a set of intercorrelated items from a pooled cross-country analysis of a large number of items ... regardless of cultural differences" and then "all items are analysed for each country separately in order to test the identity set" (Deth, 1986, p. 265), which can also show both common and different scales for every country (Deth, 1986, p. 265). As a result, "three types of comparisons of ... (1) the modes of the latent variable; (2) the level of the variable; (3) the constraint of the elements ... can be made" through this method. Deth (1986, p. 271) concludes that the development of equivalent instruments can give "meaningful information for each of these three aspects of comparative research on political participation" (Deth, 1986, p. 271).

Political and cultural contexts and their various characteristics across the world are important to consider when measuring political participation. "Political context also matters" in measuring political participation, as political behaviour differs around the world (Gaidytė, Klandermans, 2017). This is especially true for increases in various forms of political participation worldwide due to different regimes and political systems. For example, Little (1976, p. 455) describes both the Soviet and American political systems as participant systems, even "with the Soviet somewhat more so than the American", in which the fundamental differences are in the characteristics of the systems. Political participation is important "only when it affects 
the "input" side of the governmental process, that is when it has a direct effect on decision-making and policy formulation", which is present in the American system (Little, 1976, p. 443). In the Soviet system, people were broadly engaged "in the implementation of party policies", which can be "defined as "obedient participation" or the political behaviour of subjects rather than citizens" (Almond, Verba, 1968 cited in Little, 1976, p. 443).

Kalaycioglu and Turan (1981, p. 133) argue that, apart from political context, political participation can also be differentiated and measured according to its cultural contexts. They developed a measurement of political participation by extracting "three different, yet related, and meaningful dimensions of political participation" ${ }^{4}$ and employing factor analysis techniques. They used data collected from Turkey, South Korea, and Kenya to extend the "earlier studies of political participation into new cultural contexts" (Kalaycioglu, Turan 1981, pp. 125-133).

Different authors have measured political participation in a variety of ways. Many of them (e.g. Gibson, Cantijoch, 2013; Saunders, 2014; Goroshit, 2016; Oser, 2017; Ivaldi, et al. 2017; Nah, Yamamoto 2018) have utilised surveys to measure political participation. For example, Oser and Hooghe (2018, pp. 715-717) applied an actor-centred method, asking "respondents to rate the importance of various aspects of democracy" to examine the relationship between political participation and democratic ideals of citizens using the European social survey.

Many scholars have designed and applied online (e.g. Wolfsfeld, et al. 2016; Cantijoch, et al. 2016a) and Web surveys (e.g. Strömbäck, et al. 2018; Dimitrova, et al. 2014; Yamamoto, Nah, 2018; Cantijoch, et al. 2016b; Persson, Solevid 2014). A few scholars have used face-to-face surveys (see Valenzuela, et al. 2018; Kilybayeva, et al. 2017; Cantijoch, et al. 2018) and even a postal survey (for example Henn, et al. 2018, pp. 718-719) to measure political participation. For instance, Turdubaeva (2014, p. 174) employed qualitative method such as focus group interviews with average 8-10 participants in each group to examine the attitudes of politically active young people who use social network sites towards political participation in Kyrgyzstan. She had asked interviewees to fill out short questionnaires before she conducted the interviews (Turdubaeva, 2014, p. 189).

One approach that is worthy to pay attention is measuring political participation in parallel with flashpoints such as elections, upheaval, newlaws and amendments. Most recently, Henn et al. (2018), for example, examined young people's political participation in a time of austerity in Britain using

${ }^{4}$ Three dimensions are complaining, voting, and discussion. 
principal components factor analyses. In so doing, they created two factor scales for institutionalised and non-institutionalised political activities, considering the lack of consensus on how to define the institutionalised and non-institutionalised methods. These included institutionalised actions, such as voting, convincing someone to vote, campaigning, giving money to a political party, and non-institutionalised actions, such as volunteering, protesting, involvement in a youth forum, discussing politics with close people, and addressing a public issue (Henn, et al. 2018, p. 721). Young respondents were asked how likely it is that they would participate in the aforementioned non/institutionalised activities in the next few years, using a scale from one (very unlikely) to five (very likely) (Henn, et al. 2018, p. 721).

Taken together, the above-mentioned works illustrate that there is no single answer to the question on how to measure political participation. It largely depends on research question/s and focus. However, some commonalities - multifaceted nature and the number of items, political and cultural contexts, and flashpoints - should be considered when measuring political participation.

\section{MEASURING ONLINE AND OFFLINE POLITICAL PARTICIPATION}

The earlier classic works on (political) participation and democratisation can be observed in 'The Civic Culture: Political Attitudes and Democracy in Five Nations' (Almond, Verba, 1963), 'Social Mobilisation and Political Development' (Deutsch, 1961) and 'Participation and Democratic Theory' (Pateman, 1970). One such scholar, Milbrath (1965), studied political participation with regard to both individual and external factors, conceptualising it in a hierarchical structure. Verba and Nie (1987, pp. 5254) distinguished four modes (voting, campaign activity, citizen-initiated contacts, and cooperative activities) of political participation, attempting to develop the multidimensional measure of offline political participation. As the concepts of political participation adopted in various research studies include contemporary participatory forms, we need to identify how to measure both online and offline political activities of citizens (Sairambay, 2020, p.124). This is because different forms of political participation may manifest different outcomes and it is unclear whether the new forms of online activities "act in a similar manner" as offline counterparts (Cantijoch, et al. 2018, p. 17). Moreover, the measurements of online political participation have gained "a limited but increasing amount of attention" with 
the expansion of political repertoires of citizens on social-media platforms (Gibson, Cantijoch, 2013, p. 703). Therefore, we can discuss some works, such as Cantijoch et al. (2016a; 2016b) and Greuling and Kilian (2014), in terms of measuring online political participation.

Cantijoch et al. (2016 a, p. 33) analysed online political actions during the campaign using a pre- and post- election panel data and conducting multivariate analyses such as an exploratory factor analysis for eight forms of participation: "donate and e-donate, contact and e-contact, petition and e-petition and discuss and e-discuss". Their survey consisted of nine items of which three measured "engagement with the official e-campaign of the parties" and six with non-party based e-campaign and non-official e-information (Cantijoch, et al. 2016 a, pp. 34-35). As a result, their research finds that online participation is multi-dimensional and has mobilising effects that "work largely in a step-wise or 'spill-over' manner". Cantijoch et al. (2016a) argue "the 'one size fits all' approach that dominates the current literature" through showing more complex dynamics of online participation and putting e-information as "a 'gateway' or first step into participation". These findings are crucial in dealing with methodological challenges because they support the argument that political participation needs to be measured as multifaceted phenomenon in the emerging Web 3.0 era.

Greuling and Kilian (2014) explored the motivations of readers for active participation in political blogs through exploratory mixed-methods approach, applying the qualitative content and quantitative cluster analyses of eight German blogs. Similarly, Cantijoch et al. (2016b, pp. 1896-1897, 1903 ) conducted the over-time analysis of three forms of civic involvement about community activities "using an innovative mixed methodology" of a Web survey and an online weekly time diary.

Turning to the measurements of offline political participation, the following studies can be discussed. Examining the effects of digital media on political knowledge and participation in election campaigns, Dimitrova et al. (2014, p. 104) measured offline political participation through an additive index, ranging from zero (no activity) to 16 (taken part several times), asking respondents "whether, and to what extent, they engaged in eight predefined political activities during the election campaign". Other scholars, Cantijoch et al. (2018, pp. 18-21), used nine election relevant items grouped into three factors (E-Party, E-Expressive, and E-news) to measure the effects of different types of online political engagement on offline participation through simultaneous confirmatory factor analysis using structural equation modelling. 
Some scholars have measured both online and offline political participation in their research. For instance, to investigate the effects of individual news repertoires on online/offline political participation, Strömbäck et al. (2018, p. 419) measured online political participation by posing the question "During the past month, how often have you done any of the following on the Internet?" that included eight political items and a scale range from one (daily) to five (never). For offline political participation, they asked the question "During the past month, have you done the following with the intention to influence a societal issue?" that involved nine political items with three alternative responses: " 1 = Yes, several times", " 2 = Yes, once", and "3 = No" (see also Strömbäck, et al. 2018, p. 432). These question-wordings are useful to adopt and implement, although their political items are quite limited. This weakness is seen in various scholarly works below, which have also led to different items and outcomes. Yamamoto and Nah (2018) measured online and offline political participation by forming an additive index from responses for the past two years. They asked respondents whether they had done the following seven activities to measure offline political participation: attending a civic forum, contacting a mass media, signing a petition, contacting a public official, attending any demonstrations, voting in an election, and working for a political campaign (Yamamoto, Nah, 2018, p. 2076). Regarding online political participation, Yamamoto and Nah (2018, p. 2076) used four actions to measure it: "contact, contribute to, or sign up to follow a politician; volunteer for a campaign/issue; email a political message; and write a letter to the editor of a newspaper, radio, or television".

Other authors, Chan et al. (2017, p. 2009), measured offline political participation asking respondents whether they had "signed a petition; called and participated in political talk media; participated in a rally or protest; worked for a political organization; written to or called a politician or government officer; and written to or called a political or social group". For measuring online political participation, they asked whether respondents had "used social media to post pictures related to political affairs; written something about political affairs on social media; commented on or responded to a post about political affairs; signed a petition; contacted a politician or government officer; and contacted a political or social group" (Chan, et al. 2017, pp. 2009-2010). These items/actions can be expanded according to the criteria of a research focus and adopted 'political participation' concept. 
Overall, there has been an increasing number of studies on both online and offline political participation with various approaches and methods in recent years. Although scholars have employed various measurements, they neither urge the importance of current challenges surrounded the political participation research nor address them systematically so that future studies could acknowledge and deal with the issues appropriately.

\section{THE CURRENT CHALLENGES OF MEASURING POLITICAL PARTICIPATION}

Various problems that are common in measuring political participation are discussed in this section through a systematic summary from the examined 86 empirical research findings. The 'Table 1' below shows that the number of problems in measuring political participation is rising. Most of the problems are self-reported measures, different question-wordings and then the lack of acknowledging these measuring problems as well as conceptual problems, followed by misuse of Likert scales and timeframes. It should be noted that this is not a representative sample of all empirical research on political participation. Nevertheless, the analysis of these scholarly works urges the importance of considering the problems when studying political participation, at least to acknowledge and take action to rectify them accordingly. Each problem is elaborated upon in the text that follow.

Table 1: Various problems of measuring political participation in numbers, 2012-2019

\begin{tabular}{|c|c|c|c|c|c|c|c|c|c|}
\hline $\begin{array}{c}\text { № of Scholarly } \\
\text { works }\end{array}$ & 7 & 7 & 10 & 7 & 7 & 13 & 18 & 17 & $\Sigma=86$ \\
\hline $\begin{array}{c}\text { Years } \\
\text { Published } \\
\text { Problems }\end{array}$ & 2012 & 2013 & 2014 & 2015 & 2016 & 2017 & 2018 & 2019 & $\begin{array}{c}\Sigma=8 \\
\text { years }\end{array}$ \\
\hline $\begin{array}{c}\text { Lack of } \\
\text { acknowledging } \\
\text { measuring } \\
\text { challenges }\end{array}$ & 1 & 3 & 3 & 1 & 2 & 6 & 5 & 7 & $\Sigma=28$ \\
\hline $\begin{array}{c}\text { Likert scale } \\
\text { challenges }\end{array}$ & 1 & 1 & 1 & 1 & - & 2 & 2 & 1 & $\Sigma=9$ \\
\hline $\begin{array}{c}\text { Self-reported } \\
\text { measures \& } \\
\text { different } \\
\text { question- } \\
\text { wordings }\end{array}$ & 3 & 4 & 3 & 3 & 3 & 5 & 12 & 11 & $\Sigma=44$ \\
\hline
\end{tabular}




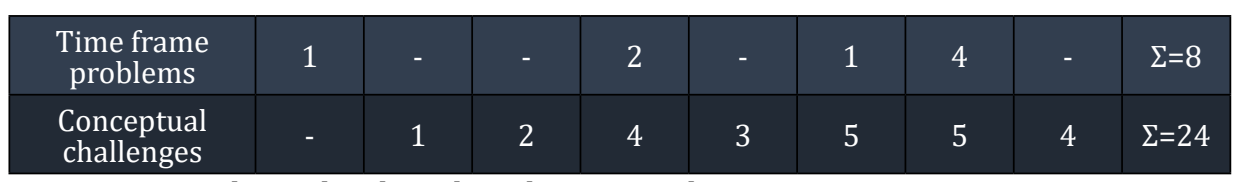

Source: Design by author based on the existing literature

The vast majority of research uses "mostly cross-sectional surveys with self-reported measures" (Dimitrova, Matthes, 2018, p. 335), which are not enough to gauge political behaviour of individuals because they do not explain how people perceive political participation and choose to act or not. Although most studies are based on cross-sectional data, some scholars such as Strömbäck, et al. (2018), Dimitrova, et al. (2014), Cantijoch, et al. (2016 a), and Moeller, et al. (2018) have already tried to establish the chain of causality through multi-wave panel surveys. However, "evidence about the causal effects" of various independent variables, such as new media, "still remains rather inconclusive" because of the lack of panel data (Strömbäck, et al. 2018, p. 425).

'Table 2' below shows some examples of various problems of measuring political participation derived from 'Table 1' sources. Scholars tend to repeat these kinds of problems in their research up to the present time, and therefore, this paper with its arguments has a potential value for other researchers in the future.

Table 2: Some examples of various problems of measuring political participation

\begin{tabular}{|c|c|c|}
\hline № & Sources & Problems and Solutions \\
\hline 1 & $\begin{array}{l}\text { Some authors (e.g. } \\
\text { Strömbäck, et al. 2018, p. } \\
\text { 419; Choi, Kwon, 2019,p. } \\
\text { 8) measure online and/or } \\
\text { offline political participation } \\
\text { without acknowledging } \\
\text { measuring challenges and } \\
\text { showing why they use } \\
\text { specific approaches/items in } \\
\text { their studies. }\end{array}$ & $\begin{array}{l}\text { It is better to acknowledge the challenges } \\
\text { of measuring political participation and } \\
\text { then offer new measurements and/or } \\
\text { approaches (if needed), showing why they } \\
\text { have been chosen and what they give us to } \\
\text { better understand political participation. } \\
\text { For example, Vissers and Stolle (2014) } \\
\text { point out that "there is no agreement with } \\
\text { regard to the measurement of political } \\
\text { participation on the Web" (Vissers, } \\
\text { Stolle } 2014 \text {, pp. 938, 943) and then they } \\
\text { show and explain their own approach in } \\
\text { conceptualising and measuring political } \\
\text { participation. }\end{array}$ \\
\hline
\end{tabular}




\begin{tabular}{|c|c|c|}
\hline 2 & $\begin{array}{c}\text { "10 items were measured } \\
\text { on a } 10 \text {-point scale ranging } \\
\text { from never (1) to all the time } \\
\text { (10)" (See Baek, 2018, pp. } \\
\text { 1144-1145). }\end{array}$ & $\begin{array}{c}\text { All the time is problematic here - it is } \\
\text { better to use very often. }\end{array}$ \\
\hline 3 & $\begin{array}{l}\text { “Offline political } \\
\text { participation was evaluated } \\
\text { using a 4-point Likert scale } \\
\text { based on eight items” (Choi, } \\
\text { Kwon, 2019, p. 8); } \\
\text { Political Participation was } \\
\text { assessed in three categories } \\
\text { on a 4-point scale (Park, } \\
\text { 2015, p. 706); } \\
\text { "To measure offline political } \\
\text { participation, we create an } \\
\text { aggregate scale composed } \\
\text { of ten modes of political } \\
\text { participation coded on a } \\
\text { four-point scale indicating } \\
\text { participation frequency" } \\
\text { (Conroy, 2012, p. 1539). }\end{array}$ & $\begin{array}{l}\text { 4-point (Likert) scales do not include } \\
\text { midpoints in between the two extremes, } \\
\text { that is, the number of the scales should } \\
\text { be odd and around five for a proper } \\
\text { data analysis. This is because people } \\
\text { sometimes find it difficult to answer if the } \\
\text { number of answers is even. This might } \\
\text { eliminate the possibility of respondents } \\
\text { to indicate true midpoint opinions (Tsang, } \\
\text { 2012). When using Likert scales without } \\
\text { midpoints, authors, at least, need to show } \\
\text { that they are aware of this fact. }\end{array}$ \\
\hline 4 & $\begin{array}{l}\text { "We use the definition } \\
\text { of political participation } \\
\text { provided by Verba } \\
\text { and colleagues (Verba, } \\
\text { Schlozman, Brady, 1995, } \\
\text { p. 9), as an 'activity that } \\
\text { is intended to or has the } \\
\text { consequence of affecting, } \\
\text { either directly or indirectly, } \\
\text { government action," } \\
\text { (Theocharis, Lowe, 2015, p. } \\
\text { 1472). }\end{array}$ & $\begin{array}{l}\text { Government action is not the only target of } \\
\text { political participation in the contemporary } \\
\text { world. Political institutions and their } \\
\text { structures can also be considered as the } \\
\text { target of political participation }\end{array}$ \\
\hline 5 & $\begin{array}{l}\text { "Over the past five years or } \\
\text { so, have you done any of the } \\
\text { following things to express } \\
\text { your views about something } \\
\text { the government should } \\
\text { or should not be doing?" } \\
\text { (Dalton, 2017, p. 233). }\end{array}$ & $\begin{array}{l}\text { Over the past five years or so is } \\
\text { problematic, as it is very imprecise and } \\
\text { undermines the reliability of the results. }\end{array}$ \\
\hline
\end{tabular}




\begin{tabular}{|c|c|c|}
\hline 6 & $\begin{array}{l}\text { "In each survey wave, } \\
\text { respondents were asked } \\
\text { whether during the } \\
\text { campaign they had (1) } \\
\text { talked to anyone about } \\
\text { politics; ..." (Towner, Muñoz, } \\
2018, \text { p. 44). }\end{array}$ & $\begin{array}{l}\text { It is inaccurate to consider talked } \\
\text { to anyone about politics as political } \\
\text { participation because it exaggerates the } \\
\text { outcomes. One might consider this action } \\
\text { as political participation only if its aim is } \\
\text { an intention to influence the outcomes of } \\
\text { political institutions and their structures. }\end{array}$ \\
\hline 7 & $\begin{array}{l}\text { “Dependent variables: } \\
\text { Political participation... } \\
\text { Each item consisted of a } \\
\text { 4-point scale ranging from } \\
\text { have never done to always" } \\
\text { (Zhang, Lin, 2018, p. 278); } \\
\text { "We measured two typical } \\
\text { types of public political } \\
\text { actions (signing petitions } \\
\text { and joining demonstrations } \\
\text { or rallies) by using 4-point } \\
\text { scales ranging from never to } \\
\text { always" (Zhang, Lin, 2018, } \\
\text { p. 279). }\end{array}$ & $\begin{array}{l}\text { Always is problematic because how } \\
\text { one can participate in political actions } \\
\text { (e.g. signing petitions and joining } \\
\text { demonstrations or rallies) always? It is } \\
\text { better to use very often instead of always. }\end{array}$ \\
\hline 8 & $\begin{array}{l}\text { “The different forms of } \\
\text { online political participation } \\
\text { asked about were as follow: } \\
\text { 1. Visit a website of a } \\
\text { political party/youth } \\
\text { organization } \\
\text { 2. Read a blog about politics } \\
\text { and society ..." (Strömbäck, } \\
\text { et al. 2018, p. 432); } \\
\text { “Online political } \\
\text { participation was also } \\
\text { measured by ... asking about } \\
\text { participation in political } \\
\text { activities such as 1) visiting } \\
\text { the web site of a party or } \\
\text { political organization; ...” (Lu, } \\
\text { et al. 2016, p. 77). }\end{array}$ & $\begin{array}{l}\text { Visiting a political website and reading a } \\
\text { political blog should not be considered } \\
\text { as political participation; they rather } \\
\text { refer to political interest or civic } \\
\text { engagement. Otherwise, these kinds of } \\
\text { actions exaggerate the research outcomes } \\
\text { (Saunders, 2014, p. 577). Visiting a } \\
\text { website and reading a blog represent } \\
\text { similar actions as watching news on TV, } \\
\text { and therefore, should not be counted as } \\
\text { political participation. }\end{array}$ \\
\hline
\end{tabular}

Source: Design by author based on the existing literature

A closer reading of the table suggests that the listed problems have solutions, which can be solved through reviewing the methodological literature of political participation research. The problem here is that there is no systematic study that has collected such problems and solutions. This paper attempts to fill this gap offering some insights into the contemporary 
challenges of measuring political participation. One step towards combating these challenges is acknowledging measuring challenges and justifying chosen approaches by authors. Otherwise, future authors might use/ repeat the same approaches/measures/items and, therefore, cause some conflicting outcomes. For instance, Strömbäck et al. (2018, p. 432) dedicated four items out of eight to 'following' any politician or political party via Twitter, Facebook, YouTube, and Instagram in measuring online political participation. Actions such as 'following' any politician or political party via social media should not be considered as online political participation. These actions are similar to reading, 'subscribing', 'joining' political groups/ news/posts and therefore represent more civic actions or political interest rather than political participation.

Survey questions vary across studies, especially in unconventional/ informal forms of political participation (Eder, Stadelmann-Steffen, 2017). Therefore, one problem of measuring political participation is what people find as 'political' when they respond to surveys (Coffe, Campbell, 2017, p. 2). Similarly, different question-wordings and techniques in surveys (even when applied to the same problem) may result in different outcomes (Persson, Solevid, 2014, p. 98). For instance, the attendance of people in legal demonstrations in West Europe in 2002 showed two different results, $27.3 \%$ and 9.3\%, in two studies (Rucht, 2007; Stoker et al. 2011 cited in Saunders, 2014, p. 577). "The different question-wording is likely to be the main explanation" for this: Rucht (2007) asked questions with no specific time period, whereas Stoker et al. (2011) asked "participation in the past twelve months" (Saunders, 2014, p. 577).

Thus, time is another issue surveys face when measuring political participation. Some researchers ask respondents about their political actions for the 'last five years or so' (Dalton, 2008 cited in Saunders, 2014, p. 577), while others ask whether respondents have 'ever' participated in political activities (Saunders, et al. 2012 cited in Saunders, 2014, pp. 579580). Saunders (2014, p. 577) critiques these time frames, claiming that one can just state one's political engagement from the distant past, for example from 1974, and this would be considered as recent data, which would exaggerate indicators of political participation. She prefers to use the time period 'in the past twelve months' to assure that respondents have been 'caught in the act' (Saunders, 2014, p. 580). This paper argues that it is better to have a shorter period, and setting time scale to measure political participation should depend on the study case and be chosen in accordance with it. If we analyse, for example, the 2011-2013 Russian protests (Snow 
Revolution), then we need to indicate this time period because 'in the past twelve months' can be used only when researching current trends of political participation. Therefore, the time frame should be sensitive to the study case and what is under examination.

Another challenge in measuring political participation is when Likert scales are misused without midpoints. Some scholars (e.g. Conroy, et al. 2012; Park, 2015; Zhang, Lin, 2018; Choi, Kwon, 2019) have used 4-point Likert scales, which do not include midpoints in between the two extremes. It is better to have scales with odd numbers; otherwise, it might be difficult for respondents to answer if they decide to show their midpoint answers. For example, in their empirical study Adelson and McCoach (2010) found that 5-point Likert-type scale is statistically higher and more reliable than the 4-point scale. Another example is when using scales from 'never' to 'very often' / 'very frequently'. This might include 'seldom' / 'rarely' and 'often' / 'frequently' options, but it would be better to have also 'sometimes' or 'occasionally' in between these two extremes. Otherwise, respondents who 'sometimes' or 'occasionally' participate in politics might have to choose between 'seldom'/ 'rarely' and 'often'/ 'frequently' if there is no midpoint such as 'sometimes' or 'occasionally'. Thus, in using Likert scales with a small number of options, such as four, one might narrow down possible answers without leaving room for midpoints, which in turn might undermine the reliability of conducted research.

Because of the ambiguous nature of political participation, measuring it is complex and requires a clear concept of political participation that the research question/s can elucidate. In other words, it would be incorrect to apply those methods designed by other scholars because 'self-reported measures' differ one from another and intend to answer study specific objectives. Thus, theoretical and methodological challenges require us to measure political participation based on research definition and question/s appropriate to the study that take into account the progress made in political participation research.

One problem in measuring political participation is its concepts that do not facilitate systematic measurements of new forms of political participation in the broader repertoires of citizens. To combat this, Theocharis and van Deth (2018, p. 115) "have proposed a solution for addressing this challenge by combining open- and closed-ended questions ... that provides examples of participatory expansions and invites citizens to mention similar activities they might have been involved in". To apply this new measurement approach, Theocharis and van Deth $(2018$, p. 86$)$ suggest to use the conceptual map 
of political participation, which was developed by van Deth in 2014. The conceptual map of political participation is about an operational definition of political participation, which consists of minimalist, targeted, and motivational definitions. It is argued by van Deth (2014, p. 349) that these three definitions along with non-political activities "cover the whole range of political participation systematically without excluding any mode of political participation unknown yet".

However, the popular concepts of political participation used in many research studies still have two problems: 1) they are aimed at influencing only the government or its structures; 2) they do not draw a clear border between political participation and civic engagement, as a result, sometimes it leads to social actions to be considered as political activities. One of the recent concepts of political participation is worthy of attention: "Political participation is any action by citizens that is intended to influence the outcomes of political institutions or their structures, and is fostered by civic engagement" (Sairambay, 2020, p. 124). First, this concept's target is not only the government or its structures, but also political institutions or their structures. Second, it differentiates civic engagement from political participation so that social activities are not considered as part of political participation.

\section{CONCLUSION}

Taken together, these findings suggest that the contemporary challenges of measuring political participation refer to various self-reported measures, different question-wordings, inappropriate use of Likert scales and timeframes as well as the lack of clear concept of political participation. The paper assists authors to avoid, or at least to address, these existing problems in their research on political participation. Otherwise, discussed problems on this paper are quite common in the literature, but have not been collected to urge their importance.

Self-reported measures and different question-wordings in surveys indicate that sometimes they are problematic or simply lead to conflicting outcomes. Therefore, it is better for scholars to work on available scholarly works and the surveys of research centres before creating own surveys. Alternatively, authors need to acknowledge measuring challenges and justify their own/new question-wordings. Measuring political participation through survey-based measurements does not explain the complexities around political participation - how and why people experience political 
participation - but instead tends to identify broad systematic patterns. One possible approach could be applying mixed research methods, both quantitative and qualitative, which might provide a more robust understanding of political participation. Another important suggestion is measuring political participation as multifaceted phenomenon in the emerging era of Web 3.0. This is because online political participation is becoming more and more popular among citizens. It has also resulted in an increase in the number of items in measuring political participation. Likert scales should contain midpoints to provide survey participants with the possibility of indicating true midpoint opinions or experiences, or at least, authors need to show that they are aware of this bias in their interpretations if they do not use midpoints. Regarding timeframes, it is better to think about the reliability of survey results and how they can be shaped by certain time frames.

The political and cultural contexts and flashpoints should also be taken into consideration when measuring political participation. One crucial component of measuring political participation is a clear concept of this phenomenon (e.g. Sairambay, 2020), which focuses on political institutions or their structures in the contemporary world and differentiates civic engagement from political participation. This differentiation might, for example, lead to sound arguments in a debate on 'clicktivism' versus 'mobilisation' theories, because in this case clicking links online would be counted as civic engagement that fosters political participation. Furthermore, it looks not only at the government and its structures as many concepts do, but also at political institutions and their structures. However, depending on a research focus and question/s one should consider an appropriate concept, taking into account the recent developments of political participation research. Thus, we can analyse the political participation concept/s in relation to where, when, and what we actually measure.

\section{REFERENCES}

ADELSON, J. L., MCCOACH, D. B. (2010). Measuring the Mathematical Attitudes of Elementary Students: The Effects of a 4-Point or 5-Point Likert-Type Scale. In: Educational and Psychological Measurement. Vol. 70, No. 5, 2010, pp. 796-807.

ALMOND, G. A., VERBA, S. (1963). The Civic Culture: Political Attitudes and Democracy in Five Nations. Princeton: Princeton University Press, 1963. 
BAEK, K. (2018). The Geographic Dimension of Citizenship in Digital Activism: Analysis of the Relationships Among Local and Global Citizenship, the Use of Social Networking Sites, and Participation in the Occupy Movement. In: American Behavioral Scientist. Vol. 62, No. 8, 2018, pp. 1138-1156.

CANTIJOCH, M., CUTTS, D., GIBSON, R. (2016a). Moving Slowly up the Ladder of Political Engagement: A 'Spill-over' Model of Internet Participation. In: The British Journal of Politics and International Relations. Vol. 18, No. 1, 2016, pp. 26-48.

CANTIJOCH, M., GALANDINI, S., GIBSON, R. (2016b). 'It's Not About Me, It's About My Community': A Mixed-Method Study of Civic Websites and Community Efficacy. In: New Media \& Society. Vol. 18, No. 9, 2016, pp. 1896-1915.

CANTIJOCH, M. C., CUTTS, D., GIBSON, R. (2018). Does Mode Matter? Measuring the Effects of Different Types of Online Political Engagement on Offline Participation. In: Comunicação Mídia e Consumo. Vol. 15, No. 43, 2018, pp. 10-40.

CHAN, M., CHEN, H-T., LEE, F. L. F. (2017). Examining the Roles of Mobile and Social Media in Political Participation: A Cross-National Analysis of Three Asian Societies Using a Communication Mediation Approach. In: New Media \& Society. Vol. 19, No. 12, 2017, pp. 2003-2021.

CHEN, Z., CHAN, M. (2017). Motivations for Social Media Use and Impact on Political Participation in China: A Cognitive and Communication Mediation Approach. In: Cyberpsychology, Behavior, and Social Networking. Vol. 20, No. 2, 2017, pp. 83-90.

CHOI, Y., KWON, G. (2019). New Forms of Citizen Participation Using SNS: An Empirical Approach. In: Quality \& Quantity. Vol. 53, No. 1, 2019, pp. 1-17.

COFFE, H., CAMPBELL, R. (2017). Understanding the Link between Citizens' Political Engagement and Their Definitions of 'Political' Activities. In: The 2017 ECPR general conference. [online]. Oslo: The European Consortium for Political Research. Available at: https://ecpr.eu/Evets/PaperDetails. aspx?PaperID=35076\&EventID=96 [Accessed October 21, 2018].

CONROY, M., FEEZELL, J. T., GUERRERO M. (2012). Facebook and Political Engagement: A Study of Online Political Group Membership and Offline Political Engagement. In: Computers in Human Behavior. Vol. 28, No. 5, 2012, pp. 1535-1546.

DALTON, R. J. (2017). The Participation Gap: Social Status and Political Inequality. Oxford: Oxford University Press, 2017. 
DETH, J. (1986). A Note on Measuring Political Participation in Comparative Research. In: Quality and Quantity. Vol. 20, No. 2, 1986, pp. 261-272.

DEUTSCH, K. (1961). Social Mobilization and Political Development. In: The American Political Science Review. Vol. 55, No. 3, 1961, pp. 493-514.

DIMITROVA, D. V., SHEHATA, A., STRÖMBÄCK, J., NORD, L. W. (2014). The Effects of Digital Media on Political Knowledge and Participation in Election Campaigns: Evidence From Panel Data. In: Communication Research. Vol. 41, No. 1, 2014, pp. 95-118.

DIMITROVA, D. V., MATTHES, J. (2018). Social Media in Political Campaigning Around the World: Theoretical and Methodological Challenges. In: Journalism \& Mass Communication Quarterly. Vol. 95, No. 2, 2018, pp. 333-342.

EDER, C., STADELMANN-STEFFEN, I. (2017). Measuring Political Participation. In: The 2017 ECPR General Conference. Oslo: The European Consortium for Political Research. [online]. Available at: https://ecpr. eu/Events/SectionDetails.aspx?SectionID=634\&EventID=96 [Accessed October 21. 2018].

GAIDYTE, T., KLANDERMANS, B. (2017). Typologies of political participation: How and Why Political Behavior Differs Across the World? In: The 2017 ECPR General Conference. Oslo: The European Consortium for Political Research. [online]. Available at: https://ecpr.eu/Events/PaperDetails. aspx?PaperID=36990\&EventID=96 [Accessed October 21, 2018].

GIBSON, R., CANTIJOCH, M. (2013). Conceptualizing and Measuring Participation in the Age of the Internet: Is Online Political Engagement Really Different to Offline? In: The Journal of Politics. Vol. 75, No. 3, 2013, pp. 701-716.

GOROSHIT, M. (2016). Political Participation: A Latent Variable Approach Testing Measurement Equivalence of Political Participation Using ESS

Data. In: Eurasian Journal of Social Sciences. Vol. 4, No. 1, 2016, pp. 26-38. GREULING, K., KILIAN, T. (2014). Motives for Active Participation in Political Blogs: A Qualitative and Quantitative Analysis of Eight German Blogs. In: Social Science Computer Review. Vol. 32, No. 2, 2014, pp. 221-237.

HENN, M., OLDFIELD, B., HART, J. (2018). Postmaterialism and Young People's Political Participation in a Time of Austerity. In: The British Journal of Sociology, Vol. 69, No. 3, 2018, pp. 712-737.

INKELES, A. (1969). Participant Citizenship in Six Developing Countries. In: The American Political Science Review. Vol. 63, No. 4, 1969, pp. 11201141. 
IVALDI, E., BONATTI, G., SOLIANI, R. (2017). An Indicator for the Measurement of Political Participation: The Case of Italy. In: Social Indicators Research. Vol. 132, No. 2, 2017, pp. 605-620.

KALAYCIOGLU, E., TURAN, I. (1981). Measuring Political Participation: A Cross-Cultural Application. In: Comparative Political Studies. Vol. 14, No. 1, 1981, pp. 123-135.

KILYBAYEVA, S., NASSIMOVA, G., MASSALIMOVA, A. (2017). The Kazakhstani Youth's Engagement in Politics. In: Studies of Transition States and Societies, Vol. 9, No. 1, 2017, pp. 53-71.

LITTLE, D. (1976). Mass Political Participation in the U.S. and the U.S.S.R: A Conceptual Analysis. In: Comparative Political Studies. Vol. 8, No. 4, 1976, pp. 437-460.

LU, Y., HEATHERLY, K. A., LEE J. K. (2016). Cross-Cutting Exposure on Social Networking Sites: The Effects of SNS Discussion Disagreement on Political Participation. In: Computers in Human Behavior, Vol. 59, 2016. pp. 74-81. http://dx.doi.org/10.1016/j.chb.2016.01.030.

MILBRATH L. W. (1965) Political Participation: How and Why Do People Get Involved in Politics? Chicago: Rand McNally \& Company, 1965.

MOELLER, J., KÜHNE, R., DE VREESE, C. (2018). 'Mobilizing Youth in the 21st

Century: How Digital Media Use Fosters Civic Duty, Information Efficacy, and Political Participation. In: Journal of Broadcasting \& Electronic Media. Vol. 62, No. 3, 2018, pp. 445-460.

NAH, S., YAMAMOTO, M. (2018). Rethinking Digital Media and Citizenship: Conditions, Contexts, and Consequences. In: American Behavioral Scientist. Vol. 62, No. 8, 2018, pp. 1019-1021.

OSER, J. (2017). Assessing How Participators Combine Acts in Their "Political Tool Kits": A Person-Centered Measurement Approach for Analyzing Citizen Participation. In: Social Indicators Research. Vol. 133, No. 1, 2017, pp. 235-258.

OSER, J., HOOGHE, M. (2018). Democratic Ideals and Levels of Political

Participation: The Role of Political and Social Conceptualisations of Democracy. In: The British Journal of Politics and International Relations. Vol. 20, No. 3, 2018, pp. 711-730.

PARK, C. (2015). Pathways to Expressive and Collective Participation: Usage Patterns, Political Efficacy, and Political Participation in Social Networking Sites. In: Journal of Broadcasting \& Electronic Media. Vol. 59, No. 4, 2015, pp. 698-716.

PATEMAN, C. (1970). Participation and Democratic Theory. Cambridge: Cambridge University Press, 1970. 
PERSSON, M., SOLEVID, M. (2014). Measuring Political Participation-Testing Social Desirability Bias in a Web-Survey Experiment. In: International Journal of Public Opinion Research. Vol. 26, No. 1, 2014, pp. 98-112.

ROLFE, M. (2012). Voter Turnout: A Social Theory of Political Participation. Cambridge: Cambridge University Press, 2012.

RUCHT, D. (2007). The Spread of Protest Politics. In: DALTON R. J., KLINGEMANN H-D. (eds.). The Oxford Handbook of Political Behaviour. Oxford: Oxford University Press, 2007, pp. 708-723.

SAIRAMBAY, Y. (2020). Reconceptualising Political Participation. In: Human Affairs, Vol. 30, No. 1, 2020, pp. 120-127.

SAUNDERS, C. (2014). Anti-politics in action? Measurement Dilemmas in the Study of Unconventional Political Participation. In: Political Research Quarterly. Vol. 67, No. 3, 2014, pp. 574-588.

SHEPPARD, J. (2015). Measuring Online and Offline Participation: Problems and Solutions from the Australian Case. In: The European Survey Research Association Annual Conference. [online]. Available at: http://www. jillsheppard.net/papers/ [Accessed October 29, 2018].

STOKER, G., SMITH, G., SAUNDERS, C., MASON, A., MCGHEE, D., OWEN, D., BANYA, M., MCGREW, T. (2011). Prospects for Citizenship. London: Bloomsbury Academic, 2011.

STRÖMBÄCK, J., FALASCA, K., KRUIKEMEIER, S. (2018). The Mix of Media

Use Matters: Investigating the Effects of Individual News Repertoires on Offline and Online Political Participation. In: Political Communication. Vol. 35, No. 3, 2018, pp. 413-432.

THEOCHARIS, Y., LOWE, W. (2015). Does Facebook Increase Political Participation? Evidence from a Field Experiment. In: Information, Communication \& Society. Vol. 19, No. 10, 2015, pp. 1-22.

THEOCHARIS, Y., VAN DETH, J. W. (2018). Political Participation in a Changing World: Conceptual and Empirical Challenges in the Study of Citizen Engagement. New York and London: Routledge, 2018.

TOWNER, T. L., LOWE, C. L. (2018). Baby Boom or Bust? the New Media Effect on Political Participation. In: Journal of Political Marketing. Vol. 17, No. 1, 2018, pp. 32-61.

TSANG, K. K. (2012). The Use of Midpoint on Likert Scale: The Implications for Educational Research. In: Hong Kong Teachers' Centre Journal. Vol. 11, 2012, pp. 121-130.

VALENZUELA, S., CORREA, T., GIL DE ZÚÑIGA, H. (2018). Ties, Likes, and Tweets: Using Strong and Weak Ties to Explain Differences in Protest Participation Across Facebook and Twitter Use. In: Political 
Communication. Vol. 35, No. 1, 2018, pp. 117-134.

VAN DETH, J. W. (2014). A Conceptual Map of Political Participation. In: Acta Politica. Vol. 49, No. 3, 2014, pp. 349-367.

VERBA, S., NIE, N. (1987). Participation in America: Political Democracy and Social Equality. Chicago and London: University of Chicago Press, 1987. WHITELEY, P. (2012). Political Participation in Britain: The Decline and Revival of Civic Culture. New York: Palgrave Macmillan, 2012.

WOLFSFELD, G., YARCHI, M., SAMUEL-AZRAN, T. (2016). Political Information Repertoires and Political Participation. In: New Media \& Society. Vol. 18, No. 9, 2016, pp. 2096-2115.

YAMAMOTO, M., NAH, S. (2018). Mobile Information Seeking and Political Participation: A Differential Gains Approach with Offline and Online Discussion Attributes. In: New Media \& Society. Vol. 20, No. 5, 2018, pp. 2070-2090.

ZHANG, X., LIN, W. (2018). Hanging Together or Not? Impacts of Social Media Use and Organisational Membership on Individual and Collective Political Actions. In: International Political Science Review. Vol. 39, No. 2, 2018, pp. 273-289. 